\title{
Sedimentation of particulate material in Nordåsvannet, a hypertrophic, land-locked fjord in western Norway
}

\author{
Paul Wassmann* \\ Department of Marine Biology, University of Bergen, N-5065 Blomsterdalen, Norway
}

\begin{abstract}
Sedimentation of particulate material to the sea bottom $(90 \mathrm{~m})$ was measured in Nordåsvannet, a land-locked, highly stratified, west-Norwegian fjord, receiving fresh water from a small glacier-free watershed and untreated domestic sewage from 30,000 persons equivalents. Five cylindrical sediment traps positioned $20,40,45,50$, and $65 \mathrm{~m}$ below the water surface were deployed from March 1982 to April 1983. Variability of seasonal sedimentation rates was small, especially at greater depths. Sedimentation rates of total particulate material and particulate organic carbon decreased from 594 and 83 at $20 \mathrm{~m}$, to 389 and $58 \mathrm{~g} \mathrm{~m}^{-2} \mathrm{yr}^{-1}$, respectively, in deeper water. Possible reasons for decreasing sedimentation with increasing depth are mineralization in the water column and lack of resuspension in deeper water. However, sedimentation rates of particulate total phosphorus and chlorophyll a equivalents increased between 20 and $45 \mathrm{~m}$ depth. These conflicting results were interpreted as a possible consequence of specific lower catchment efficiencies of the uppermost traps and artificial mineralization inside the traps. No evidence was found for sedimentational responses on time variations of suspended biomass, yet larger parts of the biomass of the spring phytoplankton bloom settled to the seafloor of Nordåsvannet. Besides fecal pellets few recognizable structures were found in the traps. The POC content of the deposited material was high compared to results given in literature and comprised 10 to $21 \%$. It is hypothesized that a large and continuous allochthonous supply of nutrients to Nordåsvannet equalizes both primary production and its sedimentation.
\end{abstract}

\section{INTRODUCTION}

Land-locked fjords are common along the west-coast of Norway, but are also found in Canada and other areas where glaciated fjord-basins predominate. The specific topographic, hydrodynamic and biological characteristics of land-locked fjords make them differ so much from typical fjords that the suggestion has been made to recognize and use internationally the Norwegian word 'poll', which means land-locked fjord (Matthews \& Heimdal 1980). Hence, the term 'poll' will be used throughout this paper.

The hydrographical conditions of polls are usually fairly stable and predictable. This, together with the limited exchange of plankton between polls and the fjords outside, and the frequently occurring stagnant

\footnotetext{
- Present address: Universitetet i Oslo, Biologisk institutt, Avd. marin zoologi og marin kjemi, P. B. 1064 Blindern, N-0316 Oslo 3, Norway
}

bottom water with an oxic/anoxic pelagic interface make polls unique marine environments and contribute to the scientific interest in poll environments. This interest is reflected by an extensive scientific and diverse literature (e.g. Strøm 1936, Richards et al. 1965, Dahl et al. 1973, Deuser 1975, Indrebo et al. 1979, Lie et al. 1983, Skei 1983a), which also include sedimentation studies (Skei 1983b, Wassmann 1983, Whitney et al. in prep.). The sedimentation of particulate matter depends on the structure and function of pelagic systems (Smetacek 1980). Monitoring of the sedimentation cycle contributes, therefore, to the understanding of the pelagic part of poll ecosystems, as well as of the supply of matter and energy to the stagnant bottom water and to the sediment.

The restricted water exchange of polls implies that they are particularly sensitive to eutrophication due to urbanization, agricultural and industrial activities. I present here preliminary data concerning depthrelated changes in sedimentation of particulate material in Nordåsvannet, a highly stratified and hyper- 


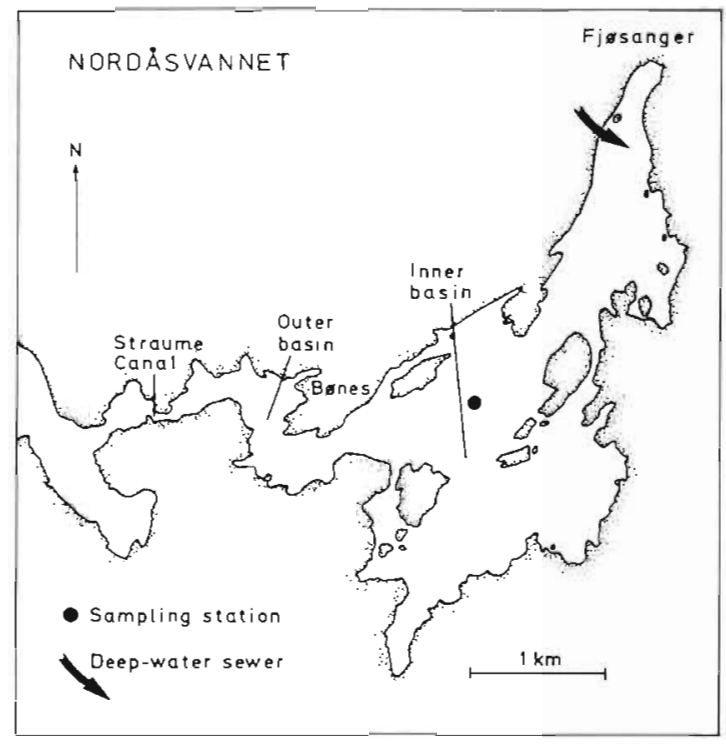

Fig. 1. Study area: Nordåsvannet, Norway

trophic poll in western Norway (Fig. 1), which, in contrast to Lindåspollene (Wassmann 1983), is used as a recipient of untreated domestic sewage from the southern part of the city of Bergen. Oceanographical data have accumulated from Nordåsvannet over a comparatively long period of about $70 \mathrm{yr}$ (e.g. Gaarder 1916, Strøm 1936, Wiborg 1944, Braarud \& Hope 1952, Glenne \& Simensen 1963, Johannessen 1972, Naas 1984). The present investigation is part of a project conducted at the Department of Marine Biology, University of Bergen. The aim of the project (Byfjordundersøkelsen) is to survey the impact of pollution from the city of Bergen on adjacent fjords (Johannessen 1983).

\section{AREA OF INVESTIGATION}

Nordåsvannet $\left(60^{\circ} 19^{\prime} \mathrm{N}\right.$ and $\left.5^{\circ} 19^{\prime} \mathrm{E}\right)$ is located approximately $7 \mathrm{~km}$ south of Bergen (Fig. 1). It consists of an outer and an inner basin separated by a threshold rising to about $10 \mathrm{~m}$ at Bønes. The inner basin is $90 \mathrm{~m}$ deep, covers $88 \%$ of the total surface area $\left(4.66 \mathrm{~m}^{2}\right)$ and contains $92 \%$ of the total volume of Nordassvannet $\left(3.710^{8} \mathrm{~m}^{3}\right.$ ) (Glenne \& Simensen 1963). The poll is connected to the outer fjord (Grimstadfjorden) by 2 parallel channels at Straume, each about $12 \mathrm{~m}$ wide and with a threshold of about $3 \mathrm{~m}$.

Nordåsvannet has a small glacier-free water shed of $86 \mathrm{~km}^{2}$ and receives about $1.310^{8} \mathrm{~m}^{3}$ fresh-water per year from a number of small streams (Glenne \& Simensen 1963). This discharge corresponds to about $35 \%$ of the total volume of the poll. During winter, Nordasvannet is usually ice-covered. The tidal range in the poll is about $35 \mathrm{~cm}$ and the water exchange during one tidal cycle corresponds to about $0.5 \%$ of the total volume. The poll receives directly and indirectly untreated domestic sewage from about 30,000 persons equivalents through an unknown number of outlets and through the rivers.

Frequency and magnitude of seawater introduction to Nordåsvannet depends on tidal height in Grimstadfjorden and freshwater supply to the poll due to precipitation and run-off from land. The restricted water exchange between the fjord outside and Nordassvannet leads to permanently anoxic conditions below 40 and $45 \mathrm{~m}$ at the sampling site (Fig. 2c). During periods of
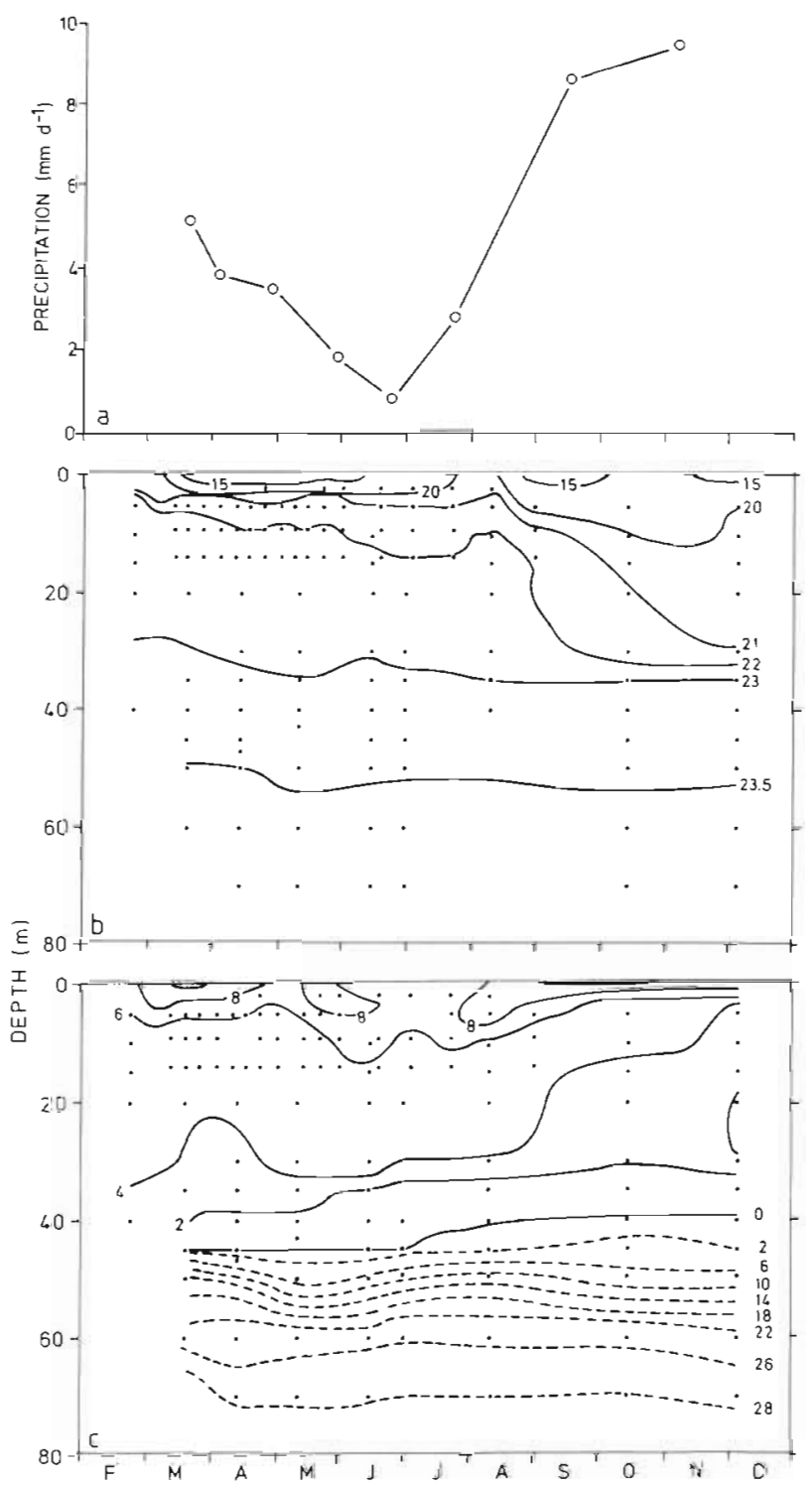

Fig. 2. (a) Average daily precipitation rates in the study area in 1982 (Bergen Airport). (b) Density $\left(\sigma_{t}\right)$ isopleths for the water column at the sampling site between February and December 1982. (c) Isopleths of oxygen and hydrogen sulfide concentration $\left(\mathrm{ml} \mathrm{l}^{-1}\right)$ in the water column at the sampling site between February and December 1982 
large freshwater run-off, surplus water is supplied to Nordåsvannet by a sewer with an outlet at $35 \mathrm{~m}$ depth (Fig. 1). This discharge, which has been in operation since 1969, induces periodic stirring of the upper $35 \mathrm{~m}$ and forced the oxycline from its former depth of 10 to $15 \mathrm{~m}$ (Wiborg 1944, Johannessen 1972) to its present depth. Complete renewal of bottom water has been observed only twice in this century, but minor exchanges of water above the oxycline are frequent (Johannessen 1985).

In 1982, the upper $5 \mathrm{~m}$ of Nordassvannet were strongly stratified in respect to density from March to
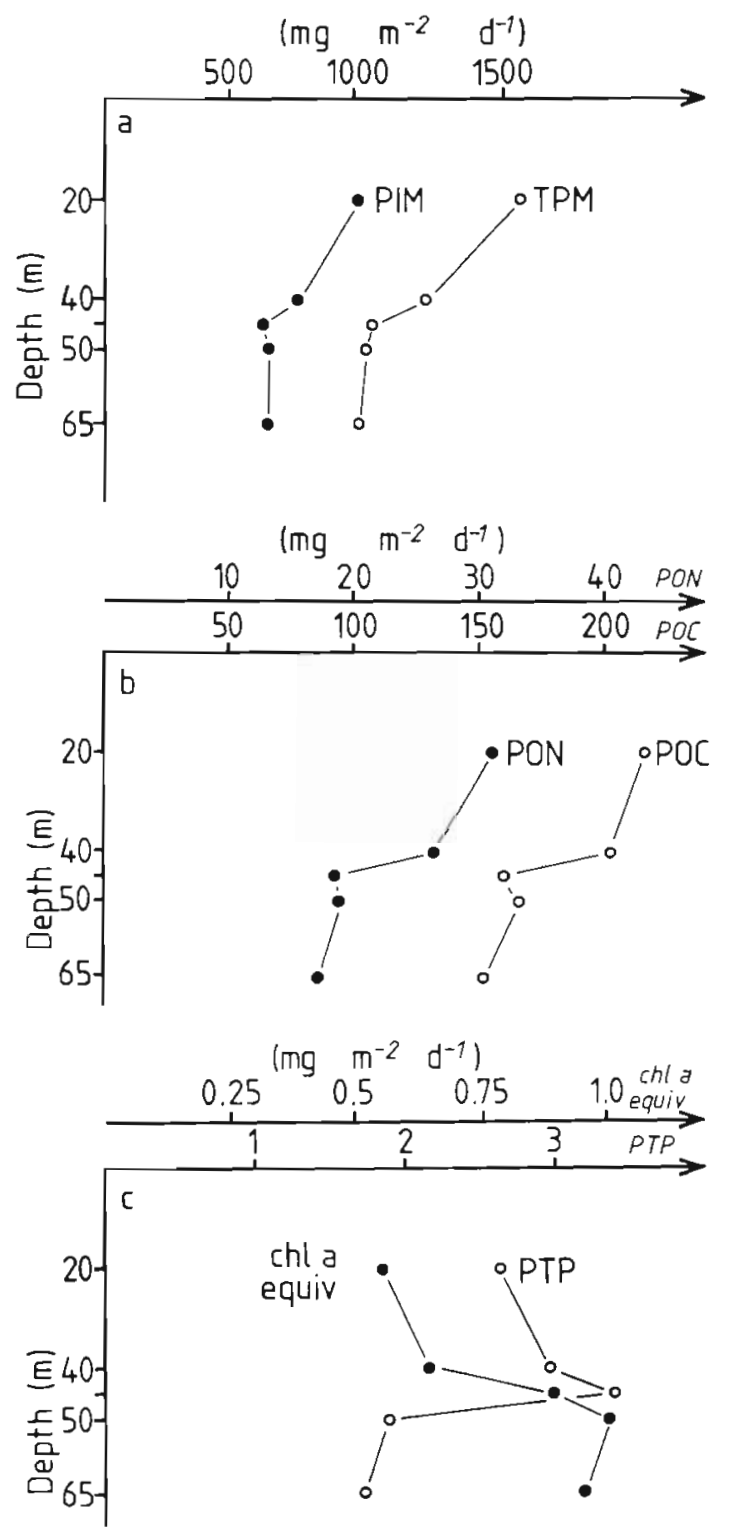

Fig. 3. Mean daily sedimentation rates of total particulate material (TPM) and particulate inorganic material (PIM) (a), particulate organic carbon (POC) and nitrogen (PON) (b), and particulate total phosphorus (PTP) and chlorophyll a equivalents (chl a equiv) (c) in relation to depth
June and from August to December (Fig. 2b). These were periods of high precipitation (Fig. 2a). Below $30 \mathrm{~m}$ only small changes in water density were found.

\section{MATERIALS AND METHODS}

Sedimentation of particulate material was measured at $20,40,45,50$ and $65 \mathrm{~m}$ depth at a central station in the inner basin with a water depth of $90 \mathrm{~m}$ (Fig. 1). During March 1982 (2 wk after the end of ice cover) to April 1983 single traps were deployed during 10 periods, ranging from 8 to $77 \mathrm{~d}$. The cylindrical stainless-steel traps had a height of $500 \mathrm{~mm}$ and a diameter of $100 \mathrm{~mm}$ (i.e. an aspect-ratio of 5), had no baffles, and were held in position by wire, clamps, anchor and subsurface floats (Wassmann 1983). Decomposition of organic matter inside the trap is known to influence the results (Bloesch \& Burns 1980, Iseki et al. 1980, Gardner et al. 1983), and chloroform ( 1 to $2 \mathrm{ml}$ ) was, therefore, added beforehand to reduce the impact of mineralization. Although the effectiveness of the preservative during deployment can be questioned, most of the chloroform was still found inside the traps after retrieval.

Subsampling, microscopic analysis, and analysis of total particulate material (TPM) and particulate inorganic material (PIM), organic material (POM), carbon (POC) and nitrogen (PON) were done as described by Wassmann (1983).

Particulate total phosphorus (PTP) was determined according to Koroleff (Grasshoff 1976). The chlorophyll and phaeopigment contents of the sedimented matter were measured fluorometrically (Holm-Hansen et al. 1965) using a Turner fluorometer. Since the presence of chloroform leads to some degradation of chlorophyll to phaeopigment during trap exposure (Hendrikson 1976), both values were added and have been expressed as chlorophyll a equivalents (chl a equiv).

\section{RESULTS}

\section{Sedimentation in relation to depth}

Mean sedimentation rates of TPM, PIM, POC and PON were greatest at $20 \mathrm{~m}$ and decreased with depth, especially between 40 and $45 \mathrm{~m}$, i.e. close to the oxycline (Fig. 3a, b). Yearly sedimentation of these components at $20 \mathrm{~m}$ was from 1.4 (PIM) to 1.9 (PON) times greater than that at $65 \mathrm{~m}$ (Table 1). In contrast, sedimentation rates of PTP and chl a equiv were greatest at 45 and $50 \mathrm{~m}$, respectively, however PTP fluxes decreased markedly at lower depths, whereas chl a equiv fluxes remained almost constant (Fig. 3c). 
Table 1. Annual gross-sedimentation rates of total particulate material (TPM), particulate inorganic material (PIM), particulate organic carbon (POC), particulate organic nitrogen (PON), particulate total phosphorus (PTP) and chlorophyll a equivalents (chl a equiv) at different depths in Nordåsvannet in 1982, and decrease in sedimentation between $20 \mathrm{~m}$ and $65 \mathrm{~m}$ expressed as a percentage of that at $20 \mathrm{~m}$

\begin{tabular}{|c|c|c|c|c|c|c|}
\hline \multirow[t]{2}{*}{ Source } & \multicolumn{5}{|c|}{ Sedimentation $\left(\mathrm{g} \mathrm{m}^{-2} \mathrm{yr}^{-1}\right)$} & \multirow{2}{*}{$\begin{array}{c}\text { Percent decrease in } \\
\text { sedimentation betweer } \\
20 \text { and } 65 \mathrm{~m}\end{array}$} \\
\hline & $20 \mathrm{~m}$ & $40 \mathrm{~m}$ & $45 \mathrm{~m}$ & $50 \mathrm{~m}$ & $65 \mathrm{~m}$ & \\
\hline TPM & 594 & 490 & 427 & 401 & 389 & 34.5 \\
\hline PIM & 357 & 299 & 271 & 258 & 256 & 28.3 \\
\hline POC & 83.0 & 80.6 & 63.0 & 62.9 & 58.4 & 29.6 \\
\hline PON & 12.2 & 11.0 & 7.5 & 7.3 & 6.6 & 45.9 \\
\hline PTP & 1.01 & 1.11 & 1.24 & 0.84 & 0.60 & 40.6 \\
\hline chl a equiv & 0.264 & 0.329 & 0.418 & 0.493 & 0.460 & - \\
\hline
\end{tabular}

Table 2. Product moment correlation coefficients (r) comparing seasonal sedimentation rates of total particulate material (TPM), particulate inorganic material (PIM), particulate organic carbon (POC), particulate organic nitrogen (PON), particulate total phosphorus (PTP) and chlorophyll a equivalent (chl $a$ equiv) at different depths in Nordåsvannet in 1982

$$
(\mathrm{n}=10)
$$

\begin{tabular}{|c|c|c|c|c|c|}
\hline \multirow[t]{2}{*}{ Source } & \multirow{2}{*}{$\begin{array}{l}\text { Depth } \\
\text { (m) }\end{array}$} & \multicolumn{4}{|c|}{ Depth (m) } \\
\hline & & 40 & 45 & 50 & 65 \\
\hline \multirow[t]{4}{*}{ TPM } & 20 & $0.68^{\circ}$ & $0.74^{\cdots}$ & 0.44 & 0.57 \\
\hline & 40 & & $0.91 \cdots$ & $0.80^{\circ}$ & $0.89^{\circ}$ \\
\hline & 45 & & & $0.80^{\circ}$ & $0.92^{*} \cdots$ \\
\hline & 50 & & & & $0.94 \cdots$ \\
\hline \multirow[t]{4}{*}{ PIM } & 20 & 0.31 & 0.37 & 0.37 & 0.50 \\
\hline & 40 & & $0.82^{\bullet}$ & $0.80^{\circ}$ & $0.73^{\circ}$ \\
\hline & 45 & & & $0.84^{\cdots}$ & $0.89^{\circ} \cdots$ \\
\hline & 50 & & & & $0.91^{\cdots}$ \\
\hline \multirow[t]{4}{*}{ POC } & 20 & $0.93^{\cdots} \cdots$ & $0.75^{\cdots}$ & $0.73^{\circ}$ & 0.50 \\
\hline & 40 & & $0.92 \cdots$ & $0.83^{\circ}$ & $0.69^{\circ}$ \\
\hline & 45 & & & $0.88^{\cdots}$ & $0.77^{\circ}$ \\
\hline & 50 & & & & $0.87^{\cdots}$ \\
\hline \multirow[t]{4}{*}{ PON } & 20 & $0.95^{\cdots}$ & $0.88^{\cdots}$ & $0.80^{\circ}$ & $0.69^{\circ}$ \\
\hline & 40 & & $0.97^{\cdots} \cdot$ & $0.82^{\cdots}$ & $0.70^{\circ}$ \\
\hline & 45 & & & $0.85^{\cdots}$ & $0.68^{\circ}$ \\
\hline & 50 & & & & $0.93 \cdots$ \\
\hline \multirow[t]{4}{*}{ PTP } & 20 & $0.87^{\cdots} \cdot$ & $0.65^{\circ}$ & -0.18 & 0.01 \\
\hline & 40 & & $0.67^{\circ}$ & -0.01 & 0.28 \\
\hline & 45 & & & 0.08 & 0.52 \\
\hline & 50 & & & & 0.07 \\
\hline chl a & 20 & $0.86 \cdots$ & $0.89 \cdots$ & $0.85^{\cdots}$ & $0.79 \cdots$ \\
\hline \multirow[t]{3}{*}{ equiv } & 40 & & $0.86^{\cdots} \cdots$ & $0.96^{\cdots}$ & $0.93^{\cdots} \cdots$ \\
\hline & 45 & & & $0.92^{\cdots}$ & $0.92^{\cdots}$ \\
\hline & 50 & & & & $0.99^{\circ} \cdots$ \\
\hline \multicolumn{6}{|c|}{$\cdot=p<0.05 ; \cdots=p<0.01 ; \cdots=p<0.001$} \\
\hline
\end{tabular}

The extent to which sedimentation differs vertically in the water column can be assessed by analysing the coherence between seasonal sedimentation rates at various depths by product moment correlation coefficients (Sokal \& Rohlf 1981) as shown in Table 2. Out of 60 correlations, 46 were statistically significant, i.e. most sedimentation rates at succeeding depths, e.g. at 20 and $40 \mathrm{~m}, 40$ and $45 \mathrm{~m}$ etc., were closely correlated, especially for POC, PON and chl a equiv. Insignificant correlations between $20 \mathrm{~m}$ and the lower depths were found for PIM. Except for PTP, all correlations below $40 \mathrm{~m}$ were significant, indicating a close coupling with respect to sedimentation below $40 \mathrm{~m}$.

\section{Seasonal patterns of sedimentation}

Seasonal patterns of sedimentation of TPM, PIM, POC, PON and PTP were fairly similar at all depths, but the time variations of the daily sedimentation rates decreased with increasing depth (Fig. 4 to 6; Table 2). Sedimentation of TPM, PIM, POC, PON and PTP increased from relatively low rates in March to maximum rates in June. Sedimentation rates were low from July to mid-August. From mid-August to January, the rates were relatively high, but decreased at most depths with time. These 3 periods of sedimentation coincided with 3 periods characterized by different stratification of the surface water, with the highest sedimentation rates occurring during periods of high stratification (Fig. 2b). Maximum sedimentation rates were found during transition from strong to less pronounced stratification by the end of June. Thus stratification seems to be of significance for the sedimentation of particulate material in Nordåsvannet.

Seasonal sedimentation rates of chl a equiv were highest from March to the middle of June, with a distinct minimum in early April (Fig. 6). Little variation was found until winter, when the sedimentation of pigments decreased to very low levels. In contrast to all other parameters, the magnitude of daily sedimentation of chl a equiv increased with increasing depth. 
TPM
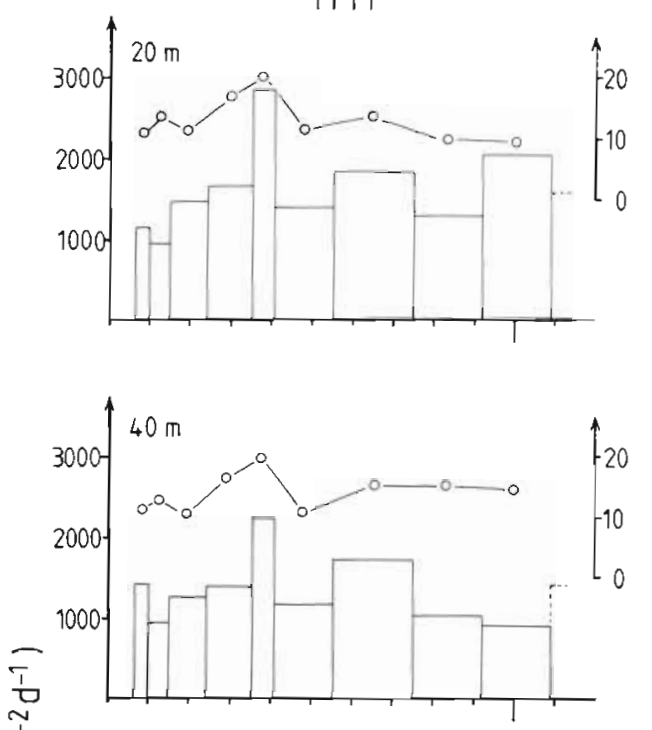

E
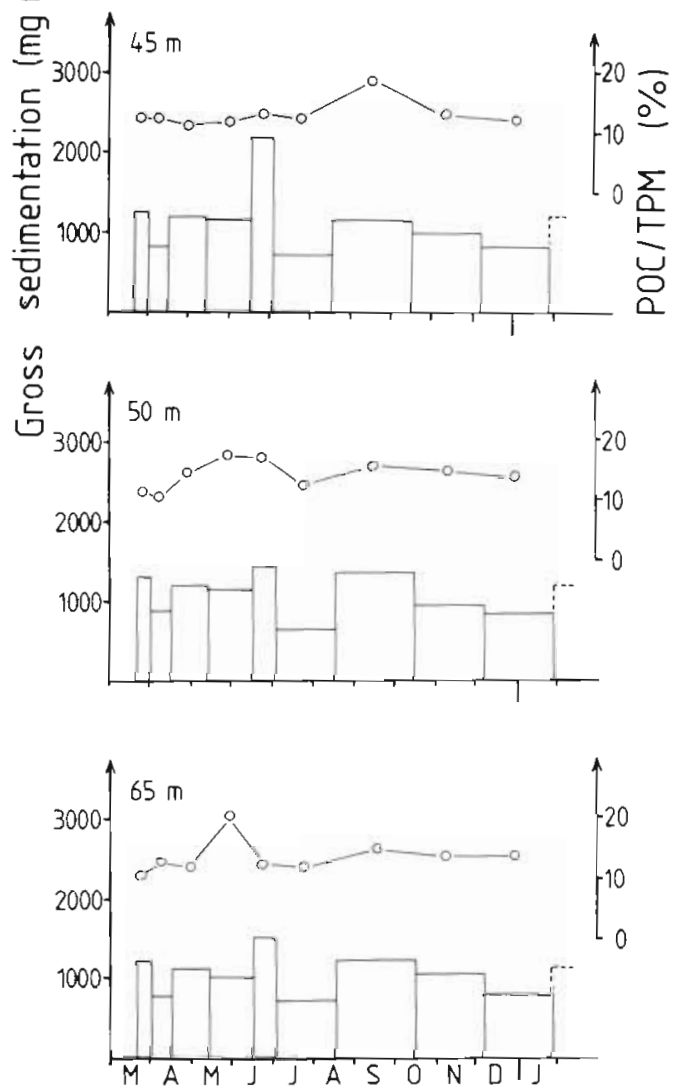

PIM
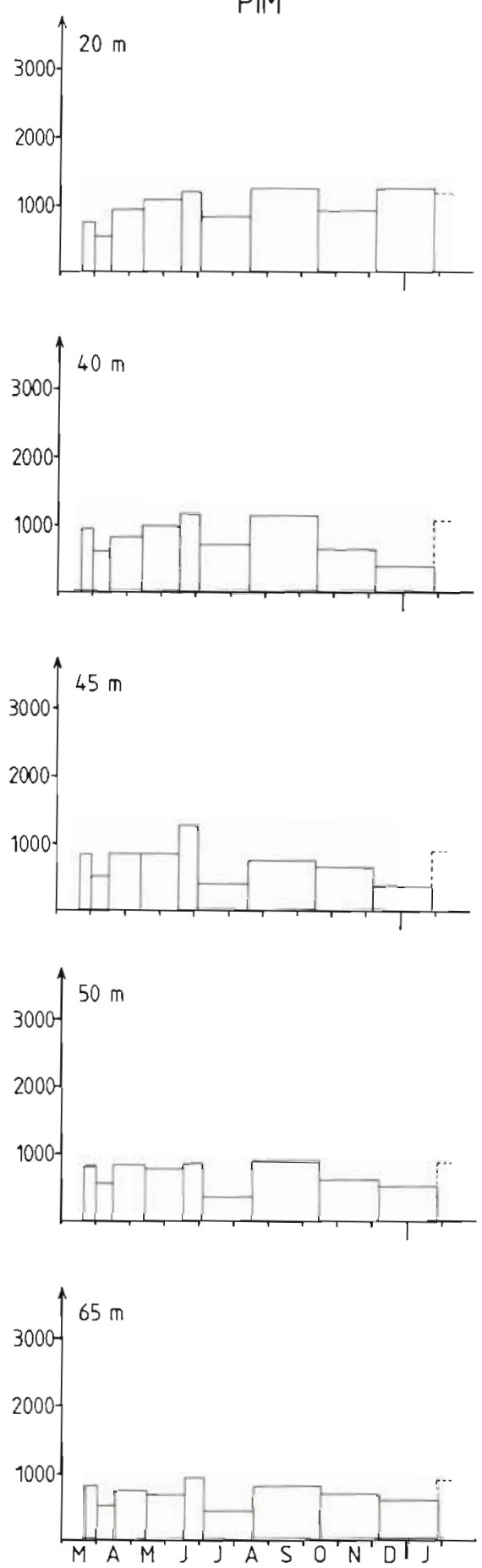

Fig. 4. Sedimentation rates of total particulate material (TPM) (left) and particulate inorganic material (PIM) (right), and the POC/TPM ratio (left) of the sedimented material at 20,40,45,50 and $65 \mathrm{~m}$ from March 1982 to January 1983 in Nordåsvannet. Daily sedimentation rates for January to April 1983 indicated by broken lines 

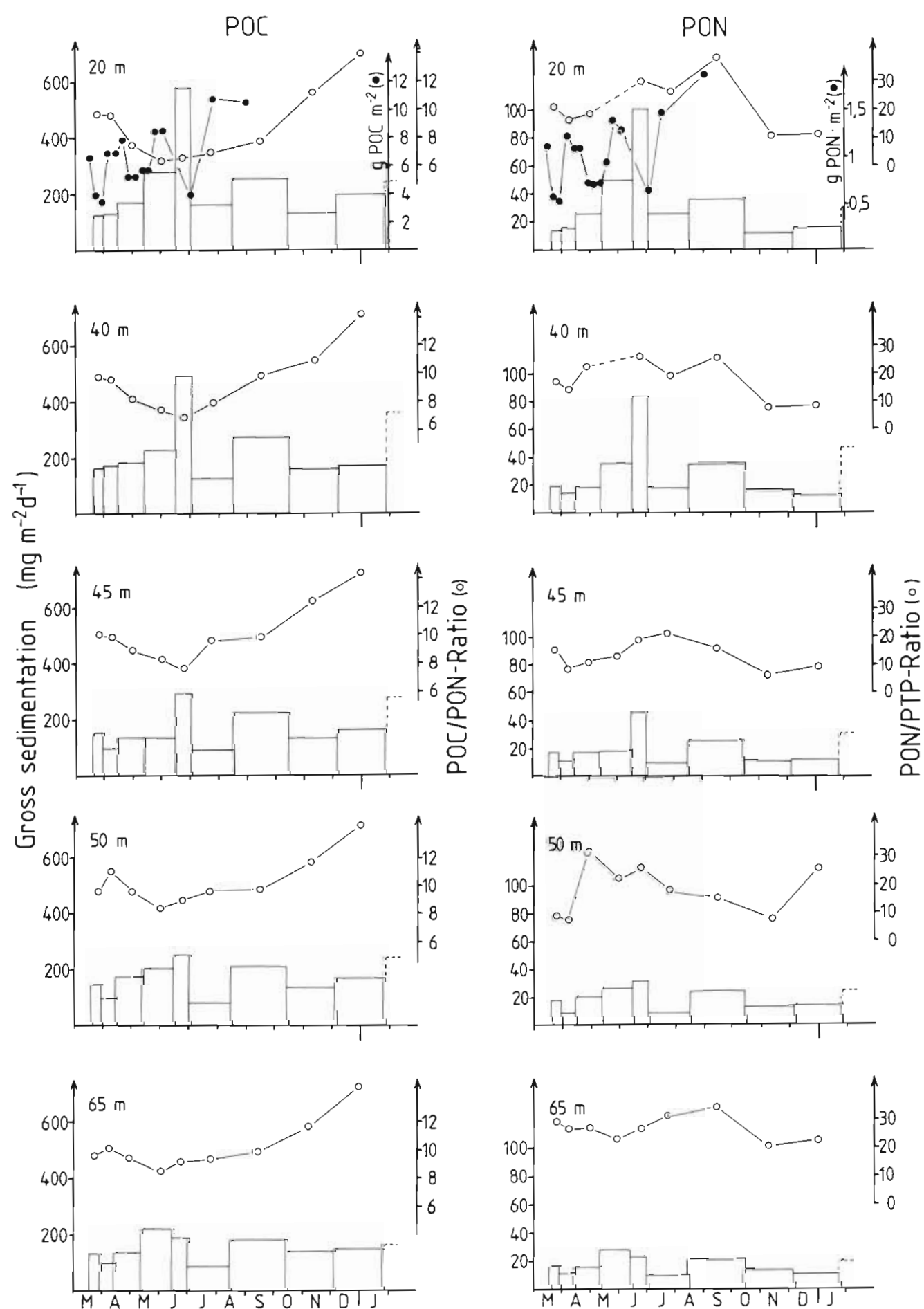

Fig. 5. Sedimentation rates of particulate organic carbon (POC) (left) and particulate organic nitrogen (PON) (right), and the atomic POC/PON (left) and the PON/PTP (particulate total phosphorus) ratios (right) of the sedimented material at 20, 40, 45, 50 and $65 \mathrm{~m}$ from March 1982 to January 1983 in Nordåsvannet. Also shown are integrated POC (upper left) and PON contents (upper right) in the upper $14 \mathrm{~m}$ of the water column (Naas 1984. K. Naas unpubl.) Daily sedimentation rates from January to April 1983 indicated by broken lines 

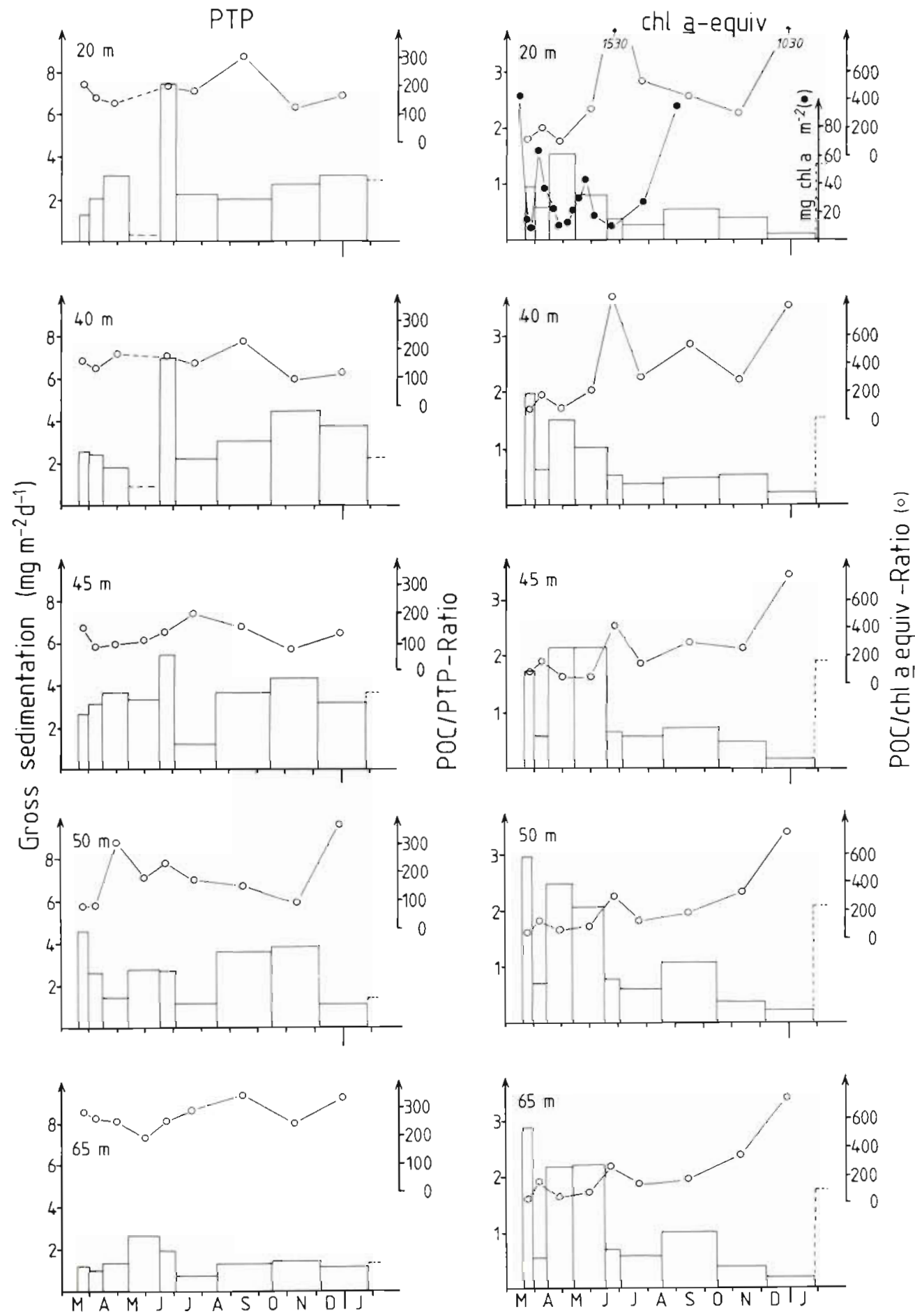

Fig. 6. Sedimentation rates of particulate total phosphorus (PTP) (left) and chlorophyll a equivalents (chl a equiv) (right), and the atomic POC/PTP ratio (left) and the POC/chl a equiv ratio (right) of the sedimented material at $20,40,45,50$ and $65 \mathrm{~m}$ from March 1982 to January 1983 in Nordassvannet. Also shown is the chlorophyll a content (upper right) of the upper $14 \mathrm{~m}$ of the water column (Naas 1984, K. Naas unpubl.) Daily sedimentation rates from January to April 1983 indicated by broken lines 
No obvious correspondence was found between biomass parameters in the upper $14 \mathrm{~m}$ of the water column such as POC, PON (Fig. 5), and chlorophyll a (Fig. 6) (Naas, 1984) and sedimentation of POC, PON and chl a equiv, indicating that particulate material derived from phytoplankton is not rapidly or only in part transferred to the deeper layers of the poll. Thus, the seasonal variation in sedimentation of organic material might also be influenced by factors other than phytoplankton biomass. No significant product moment correlations between precipitation, which determines run-off from land (Fig. 2a), and sedimentation were found.

\section{Nature of sedimented material}

Microscopic examination revealed that most of the sedimented material in the traps consisted of small amorphous aggregates and flakes, the amount of which decreased with increasing depth. Recognizable structures were mainly small, oval or cylindrical fecal pellets which were found throughout the period of investigation. A few diatoms (Thallassiosira sp.), but no other species, were found. There was no obvious depth-related difference in sedimentation of fecal pellets.

The relative POC content of TPM showed small seasonal variations, ranging between 10 and $21 \%$ with an average of $14.5 \%(n=50)$ (Fig. 4). Little variation was also found in relation to depth (Fig. 7 a). It should be recognized that the POC content in Nordassvannet is not only influenced by phytoplankton, but also by a continuous import of domestic sewage and fresh water run-off. The influence of varying POC content of phytoplankton will, therefore, assumedly be less on the POC content of sedimented TPM in Nordåsvannet than in unpolluted polls.

The POC/PON ratio of the sedimented matter varied both with season (Fig. 5) and depth (Fig. 7b), revealing changes in the composition of the organic material. The ratio ranged between 5.5 and 12.5 with an average of $8.5(\mathrm{n}=50)$. The pattern of seasonal variation was generally similar at all depths - with relatively high values in spring, fall, and winter and low values in summer (Fig. 5). Mean ratios increased between 20 and $65 \mathrm{~m}$, mostly between 40 and $45 \mathrm{~m}$ (Fig. 7b) and showed a reverse trend to that of sedimentation rates (Fig. 3b). This indicates that organic material deposited below the oxycline is more nitrogen depleted than above. No obvious coherence was found between the seasonal sedimentation rates at the various depths and their corresponding POC/PON ratios.

The changes in the PON/PTP and POC/PTP ratios were similar both with time (Fig. $5 \& 6$ ) and depth (Fig.

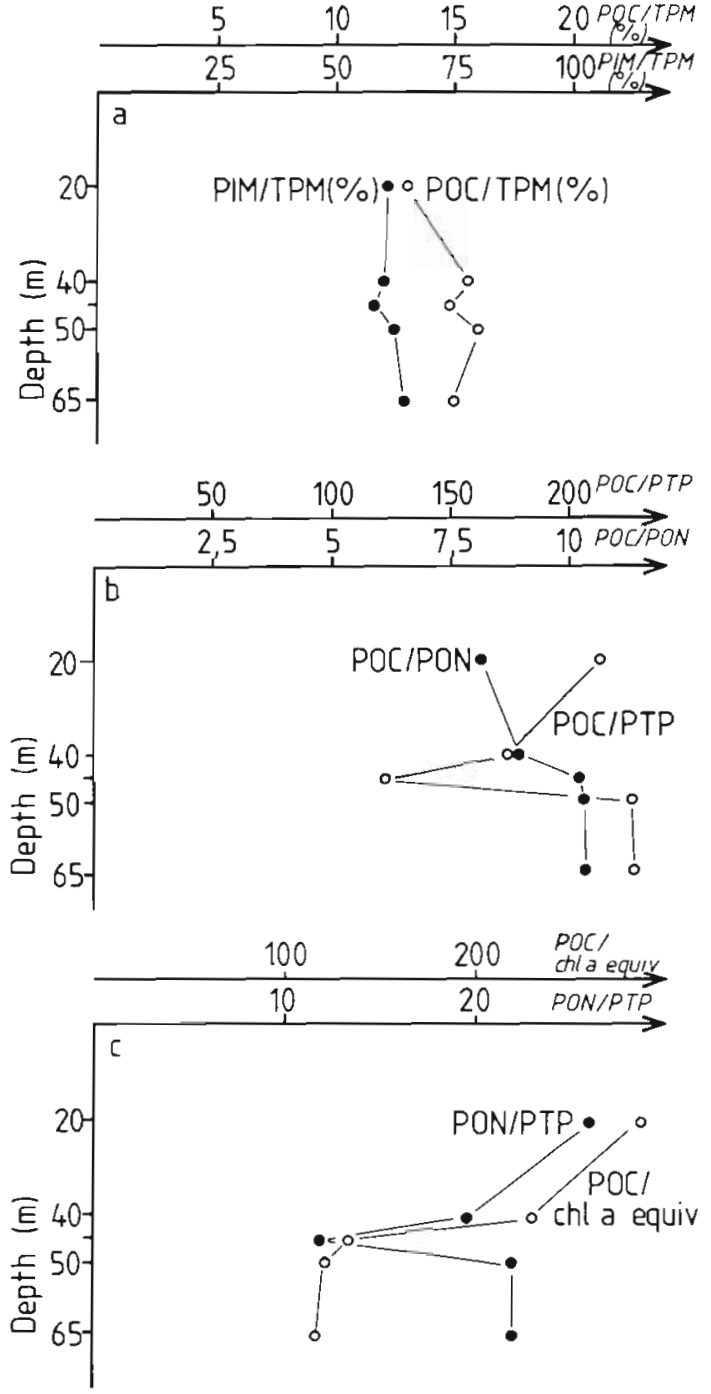

Fig. 7. Average ratios in relation to depth. (a) Particulate inorganic matter (PIM) and particulate organic carbon (POC) as weight percentages of total particulate matter (TPM). (b) POC/PON (particulate organic nitrogen) and POC/PTP (particulate total phosphorus) atomic ratios. (c) PON/PTP atomic ratio and $\mathrm{POC} /$ chlorophyll $a$ equivalents ratio (w/w)

$7 \mathrm{~b}, \mathrm{c})$, reflecting the relatively small variation between POC and PON compared to the variations between POC and PTP and between PON and PTP. The mean PON/PTP and POC/PTP ratios decreased from 26 and 210 at $20 \mathrm{~m}$ to 12 and 130 at $45 \mathrm{~m}$, respectively (Fig. $7 \mathrm{~b}$, c), indicating that the organic matter deposited in the trap at $20 \mathrm{~m}$ was far more depleted of phosphorus than at $45 \mathrm{~m}$. At $45 \mathrm{~m}$ the mean POC/PTP ratio approximates the theoretical Redfield-ratio (Redfield et al. 1963) for fresh organic material, i.e. 106. The mean PON/PTP ratio at $45 \mathrm{~m}$ was, on the other hand, lower than the average Redfield-ratio of 16 . Possible reasons for the apparent discrepancy between sedimentation of POC and PON on the one hand and of PTP on the other 
(Fig. 3b, c; Fig. 7b, c) could be increased phosphorus assimilation with increasing depth, precipitation of dissolved phosphorus close to the oxycline, increased dissolution of PTP relative to POC and PON in the traps exposed to oxygenated water, weakly adsorbed PTP or analytical problems. Below the oxycline the PON/PTP and POC/PTP ratios increased to about 22 and 250, respectively, with little further changes with depth. The PON/PTP and POC/PTP ratios (Fig. $5 \& 6$ ) showed great seasonal variations, ranging from 6 to 40 and 80 to 380 , respectively. The variations were fairly similar at 20,40,45 and $65 \mathrm{~m}$, where the organic matter deposited had the lowest phosphorus content during summer and fall. The seasonal pattern was different at $50 \mathrm{~m}$ where the most P-depleted organic matter was deposited in April and December/January (Fig. 5 \& 6).

The $\mathrm{POC} / \mathrm{chl}$ a equiv ratio was lowest in the period April to June when it varied between 40 to 340 with an average of $125(n=20)$ (Fig. 6). The organic matter deposited during the peak of sedimentation at the end of June (Fig. 4 \& 5) was poor in plant pigments and the $\mathrm{POC} / \mathrm{chl}$ a equiv ratio was high, especially at 20 and $40 \mathrm{~m}$. From summer to winter the ratio generally increased to a mean value of 890 in December and January, mainly due to the decrease in sedimentation of chl a equiv. The mean $\mathrm{POC} / \mathrm{chl}$ a equiv ratio decreased with depth from 310 at $20 \mathrm{~m}$ to 150 at $45 \mathrm{~m}$ (Fig. 7c); it showed in this depth interval a variation similar to PON/PTP and POC/PTP ratios. Below $45 \mathrm{~m}$ the $\mathrm{POC} / \mathrm{chl}$ a equiv ratio revealed only a slight further increase.

\section{DISCUSSION}

Decrease in sedimentation with depth in Nordåsvannet (Fig. 3a, b) is in agreement with the depth related sedimentation in Lindâspollene (Wassmann 1983), but is in contrast to the increase in sedimentation with depth found in many other coastal environments (Steele \& Baird 1972, Ansell 1974, Hargrave \& Taguchi 1978, Smetacek 1980). Increase in sedimentation with increasing depth is usually interpreted as a result of resuspension. Due to the specific hydrographic conditions in poll environments (Strøm 1936, Dahl et al. 1973, Johannessen 1984), turbulent water movement and resuspension are here restricted to the upper part of the water column. Consequently, secondary sedimentation of resuspended matter does not increase with depth. As judged from numerous hydrochemical profiles at the sampling site (Johannessen 1972, 1983) the sediment vessels at $40 \mathrm{~m}$ and below were situated in almost stagnant water and only slightly affected by resuspension. Some turbulence is induced in the upper $40 \mathrm{~m}$ due to the outlet at $35 \mathrm{~m}$ depth which discharges surplus freshwater during rainy periods. In addition, there are lateral water movements caused by the tide in the surface water, apparently restricted in the inner basin to the upper $10 \mathrm{~m}$, which is the threshold depth at Bønes (Fig. 1). The sediment vessel at $20 \mathrm{~m}$ could, therefore, have been subjected to some water currents. In regard to the moderate hydrodynamic conditions in the deeper water layers of polls, cylinders with an aspect-ratio greater than 3 are the adequate design (Hargrave \& Burns 1979, Gardner 1980, Bloesch \& Burns 1980, Blomqvist \& Håkanson 1981, Blomqvist \& Kofoed 1981). Consequently, the present results are probably close to net-sedimentation rates at the different depths and represent the actual downwards flux of particulate material in the centre of the poll. However, one cannot be sure that the actual catchment efficiencies of cylinders in respect to particles of different size, composition and shape are constant even in slightly different turbulent regimes. The depth-related differences in sedimentation could also be influenced by vertically migrating zooplankton grazing in surface waters and releasing fecal pellets at greater depth. However, compared to fjords poll ecosystems are dominated by small zooplankton forms (Matthews \& Heimdal 1980) which presumably produce small fecal pellets with lower settling rates. Also, vertical migration of zooplankton populations of polls is insignificant (Lie et al. 1983). It was previously hypothesized from studies in Lindasspollene that the combined effects of depth related decrease of secondary sedimentation and high recycling rate in the oxic part of the water column results in a depth related decrease of gross sedimentation below the euphotic zone of polls (Wassmann 1983). This hypothesis seems to be valid also for the present study.

The rate of sedimentation decreased between the uppermost and the lowermost trap, with 28 to $46 \%$ in Nordåsvannet (Table 1), compared to 69 to $87 \%$ in Lindåspollene (Wassmann 1983). This could reflect a real difference between the 2 polls, however, sedimentation rates at $20 \mathrm{~m}$ could be relatively much greater in Lindåspollene, as the euphotic zone can reach down to ca. $20 \mathrm{~m}$ close to the trap, while in Nordassannet it is restricted to $10 \mathrm{~m}$ (Naas 1984 ). The sedimentation rate at the bottom of the euphotic zone in Nordåsvannet is, therefore, possibly higher in Nordåsvannet than that measured at $20 \mathrm{~m}$. As sedimentation rates in polls can differ distinctly over few meters of depth intervals ( $\mathrm{T}$. Ordemann pers. comm.), a detailed pilot study of depth related sedimentation should, therefore, preferably precede annual sedimentation surveys in polls.

The apparent high sedimentation rates of PTP and chl a equiv in 40 to $45 \mathrm{~m}$ depth above the oxic/anoxic interface are in contrast to TPM, PIM, POC and PON sedimentation (Fig. 3). This finding deviates from the 
view that the traps in Nordassvannet were suspended in stagnant or slowly moving water where the amount of sedimenting particles can decrease with depth due to decomposition, leaching or dissolution, but not increase. In the case of chlorophyll and its decomposition products it was observed that the filtrate of the sediment suspension had a greenish colour, especially in the $20 \mathrm{~m}$ samples. This implies that some decomposition, leaching and dissolution of pigments took place inside the traps during exposure. Possibly the added chloroform played a role in this process. However, the decomposition of phaeopigments, the primary degradation product of chlorophyll (Lorenzen 1967), is diminished under anoxic conditions, as they are well preserved in anoxic water (Lorenzen 1974) and fjord sediments (Tett 1982). Dissolution and leaching of pigmented matter in the dark could, therefore, be dependent on the presence of oxygen. Since the oxygen concentration in Nordassvannet decreases with depth (Fig. 2c), the pigment dissolution also apparently decreased. The amount of chl a equiv present inside the traps at the time of retrieval increased, consequently, with increasing depth, but showed minor variation in the traps exposed at different depths in the anoxic part of the water column (Fig. 3c). If this explanation is correct, sedimentation rates of chl a equiv were thus underestimated in the oxic part of the water column. However, increasing pigment sedimentation rates and decreasing $\mathrm{POC} / \mathrm{chl} a$ equiv ratios with increasing depth were also recognized in an open fjord (Lorenzen \& Welshmeyer 1983) and the Baltic Propper (Smetacek et al. 1978). These authors explain the increasing significance of pigments in the sedimented material with increasing depth as the result of decreasing zooplankton coprophagy and different catchment efficiencies of the traps, respectively.

In contrast to the rather unchanged sedimentation rates of chl a equiv below $45 \mathrm{~m}$, sedimentation of PTP decreased markedly in the upper part of the anoxic zone (Fig. 3c). Richards et al. (1965) found that phosphate was regenerated more rapidly than other nutrients in these layers of the poll Lake Nitinat. In addition, the total amount of phosphorus in water samples from the anoxic zone of Nordåsvannet was comprised mainly of orthophosphate (Johannessen 1983). It is, therefore, possible that much of the particulate phosphorus was dissolved below the oxic/anoxic interface. Above $45 \mathrm{~m}$ PTP-sedimentation resembled that of chl a equiv (Fig. 3c), and it is assumed that oxygen dependent mineralization and leaching inside the traps also caused the apparently increasing sedimentation rates of PTP. Thus, Knauer \& Martin (1981) found much orthophosphate inside traps exposed in well oxygenated water columns. They concluded that they were either missing similar amounts of dissolved organic $\mathrm{C}$ and $\mathrm{N}$ and thus underestimated vertical fluxes for all 3 elements, or that large pools of weakly sorbed phosphate were associated with suspended organic detritus. The latter is a very possible explanation in view of reports of elevated phosphate concentrations associated with marine snow particles (Shanks \& Trent 1979) and can also explain the contrasting sedimentation profiles of PTP compared with POC and PON observed in this study.

These conflicting results once more raise the question of how samples in sediment vessels change quantitatively and qualitatively during exposure (Iseki et al. 1980, Gardner et al. 1983). We do not know the decay rate of organic particles collected in traps and its importance for the determination of the flux of organic matter. Therefore, preservatives are applied to prevent artificial mineralization inside the traps although it has been questioned, whether the use of poisons is an essential or superfluous exercise (Bloesch \& Burns 1980, Lee et al. 1983). By the poisons at least the impact of grazing inside the traps is reduced (S. Blomqvist, T. Ordemann pers. comm.). The sedimentation rates measured in this study are probably underestimates of the real vertical fluxes, particularly of phosphorus and plant pigments. This is especially so since fairly long trap exposure times had to be used for practical reasons. The exposure time of unpoisoned traps should not exceed $3 \mathrm{wk}$, if questions of settling fluxes of particulate organic matter are considered, and results on organic materials obtained from traps left 1 mo or longer are questionable (Bloesch \& Burns 1980). More work on the decay of organic matter inside traps and the effect of poisons is clearly needed. As long as the significance of different sources of sedimenting matter in Nordassvannet and the diagenesis of the traps is little known, characterizing the nature of deposited material by ratios such as $\mathrm{POC} / \mathrm{PON}, \mathrm{POC} / \mathrm{chl}$ a equiv etc. is inconclusive.

Imbalances between primary and secondary production in coastal areas occurring in spring (Fransz 1976, Gieskes \& Kray 1977, Smetacek 1980, Peinert et al. 1982) and often referred to low hibernating zooplankton biomass result in high sedimentation rates by diatom populations at the end of the spring phytoplankton bloom. This has also been observed in the poll Lindåspollene (Skjoldal \& Lännergren 1978, Wassmann 1983). The decrease in dissolved nutrients, often with silicate as the main limiting nutrient, brings the spring phytoplankton bloom to an end in coastal areas of Norway (Lännergren \& Skjoldal 1976, Erga \& Heimdal 1984). Silicate depletion elicited by far the greatest increase in sinking rates of diatoms (Bienfang et al. 1982). However, no indications of increased bulk sedimentation rates in March and April were found in Nordåsvannet in 1982 (Fig. 4 \& 5) as the first phyto- 
plankton spring bloom of mid March occurred before the traps were deployed (Naas 1984). Only increased amounts of pigmented matter were supplied to the anoxic water during this period, indicating that freshly produced organic matter with low POC/chl a equiv ratio settled to the seafloor (Fig. 6). However, the high sedimentation rates at the end of March and the distinct minimum in early April possibly represent the end of phyto-detritus sedimentation of the phytoplankton spring bloom. For the period 27 January to 14 April, 1983, evidence of increased sedimentation rates of all fractions, especially chl a equiv, as indicated in Fig. 4 to 6 , is provided. Due to the length of this period ( $77 \mathrm{~d}$ ), the actual daily sedimentation rates in connection with the spring phytoplankton bloom could not be exactly calculated. Afterall, it is concluded that a portion of the biomass produced by the spring phytoplankton settles to the seafloor in Nordåsvannet, too, but the magnitude of this increased sedimentation rate is smaller than in other coastal areas (Peiner et al. 1982, Wassmann 1983).

In contrast to unpolluted polls, such as Lindåspollene, dissolved inorganic nutrients rarely decrease to low levels in the surface water of Nordassvannet (Johannessen 1983, Naas 1984). If phosphate and ammonium supply rates by domestic sewage from 30,000 persons equivalents are assumed to be 17 and 500 mmole person ${ }^{-1} \mathrm{~d}^{-1}$ (J. Magnusson pers. comm.), respectively, the annual sewage input corresponds to about 40 and 1200 mmole $\mathrm{m}^{-2} \mathrm{yr}^{-1}$ of phosphate and ammonium, respectively. For comparison, this input of ammonium would be equivalent to an annual primary production of $87 \mathrm{~g} \mathrm{C} \mathrm{m}^{-2}$, assuming a $\mathrm{C} / \mathrm{N}$ ratio of 6 , if all was utilized by phytoplankton. The total primary production in 1982 was estimated to be $190 \mathrm{~g} \mathrm{C} \mathrm{m}^{-2}$ $\mathrm{yr}^{-1}$ (Wassmann et al. 1984). Evidently, sewage supply gives rise to about $50 \%$ of the total primary production. Phytoplankton production in Nordassvannet is thus unlikely limited by nutrients, yet the turbidity of the surface water seems to be a main regulating factor (Naas 1984). The concepts of 'new' and 'recycled' production (Dugdale \& Goering 1967) are not totally adequate for an understanding of the cycle of organic matter in Nordassvannet, since the externally supplied nutrients to a great extent are the same chemical species as those recycled by the excretory activities of zooplankton and microorganisms. In contrast to 'new' production in more typical oceanographic situations which favor growth of diatoms, the phytoplankton community in Nordåsvannet is rich in flagellates during spring and summer (Naas 1984). However, during some periods larger quantities of diatoms (Skeletonema sp., Chaetoceros sp., Thallassiosira sp.) were recorded. The zooplankton community is quite rich (Johannessen 1972), and there is no doubt that 'recycled' production also contributes considerably to the total primary production. Recycling of organic matter apparently influences the sedimentation in Nordåsvannet to a lesser degree than in Lindasspollene, where recycling during summer and fall was so important that 2 loosely coupled sedimentation regimes in the upper and lower water layers, respectively, were found (Wassmann 1983). In Nordåsvannet, however, sedimentation rates at all depths, especially for POC, PON and chl a equiv, were in general closely correlated (Table 2). This coupling of the upper and lower layers of the water column is possibly the consequence of the continuous allochthonous supply of nutrients which equalizes the production of organic matter and its sedimentation. Small variability in sedimentation is, compared to other studies, well reflected in Fig. 4 to 6. However, the sampling intervals were probably too long to indicate short time variatons in sedimentation. It is, therefore, important that the high sedimentation rates at the end of June were observed during a comparatively short time interval.

In addition to the supply of domestic sewage through sewers to the surface water, eddy diffusion of nutrients from the extremely rich water below the euphotic zone is of significance. This diffusion is probably intensified by the circulation induced by the discharge at $35 \mathrm{~m}$ depth of surplus freshwater during rainy periods. 1982 was an unusually sunny period with very low precipitation rates in June, July and early August (Fig. 2a) that resulted in a distinct lowering of the stratification of the upper layers (Fig. 2b), decreased nutrient concentration in the surface water (K. Naas unpubl.), and an increase in Secchi-disk readings. Low suspended concentrations of POC, PON, and chlorophyll $a$ by the end of June coincided with high sedimentation rates (Fig. 4 to 6). This was possibly a consequence of nutrient shortage during summer representing a parallel to sedimentation of phytoplankton spring bloom (Smetacek 1980, Wassmann 1983). However, during summer 1982 the nutrient concentration in the lower part of the euphotic zone did not limit primary production (Wassmann et al. 1984). Moreover, the amplitude of the sedimentation pulse decreased distinctly with depth (Fig. 4 to 6) and the material was very low in chl $a$ equiv at 20,40 and $45 \mathrm{~m}$ (Fig. 6), indicating that the material deposited was not of freshly produced origin. The POC/PON-ratio of this pulse was low, indicating that the material caught by the upper traps was not nitrogen depleted. This could possibly be due to colonization and mineralization of phytoplankton detritus by bacteria which, generally speaking, have great influence on the relative composition of settling particles (Iturriaga 1979). Therefore, increasing POC/PON and decreasing POC/PTP ratios of deposited material in the upper $45 \mathrm{~m}$ of Nordåsvannet could also be inter- 
preted as a result nitrogen mineralization and phosphate uptake by bacteria colonizing settling particles.

Compared to the unpolluted polls Lindasspollene (Wassmann 1983) and Framvaren (Skei 1983a) where 23 and $13 \mathrm{~g} \mathrm{C} \mathrm{m}^{-2} \mathrm{yI}^{-1}$, respectively, were supplied to the sediment surface, the POC sedimentation rate at $65 \mathrm{~m}$ in Nordåsvannet was much higher (Table 1). This is obviously the result of eutrophication. Compared to open fjords and coastal areas, however, the supply of organic matter to the anoxic part of Nordassvannet is in the lower range of sedimentation rates and the organic content of the sedimented matter is high (see Table 5 in Wassmann 1983). Eutrophicated polls can, therefore, be characterized by low TPM sedimentation rates with high organic contents.

Acknowledgements. I gratefully acknowledge the support and advice of $U$. Lie and thank the crew of R. V. 'August Brinkmann, d. e.' for good collaboration in the field; F. L. Daae for help with the POC/PON analysis; and P. Johannessen and K. Naas for valuable discussions. I am grateful to $S$. Blomqvist, V. Smetacek and especially to J. Bloesch and H. R. Skjoldal for offering comments on the manuscript. This work was supported by the Byfjord-undersøkelsen and by a Deminex-grant of the Royal Norwegian Council for Scientific and Industrial Research (NTNF).

\section{LITERATURE CITED}

Ansell, A. D. (1974). Sedimentation of orgaric detritus in Loch Etive and Ceran, Argyll, Scotland. Mar. Biol. 27: 263-273

Bienfang, P. K., Harrison, P. I., Quarmby, L. M. (1982). Sinking rate response to depletion of nitrate, phosphate, and silicate in four marine diatoms. Mar. Biol. 67: 295-302

Bloesch, J., Burns, N. M. (1980). A critical review of the sediment trap technique. Schweiz. Z. Hyclrol. 42: 15-55

Blomqvist, S., Kofoed, C. (1981). Sediment trapping - a subaquatic in situ experiment. Limnol. Oceanogr. 26: 585-590

Blomquist, S., Håkanson, L. (1981). A review on sediment traps in aquatic environments. Arch. Hydrobiol. 91: 101-132

Braarud, T., Hope, B. (1952). The phytoplankton cycle of a landlocked fjord near Bergen (Nordåsvannet). Reports on Norwegian Fishery and Marine Investigations, Vol. 9, No. 16 , pp. 26

Dahl, O., Østvedt, O., Lie, U. (1973). An introduction to a study of the ecosystem and the local herring stock in Lindåspollene. FiskDir. Skr. (Ser Havunders.) 16: 148-158

Deuser, W. G. (1975). Reducing environments. In: Riley, J. P., Skirrow, G. (ed.) Chemical oceanography, Vol. 3. Academic Press, London, p. 1-37

Dugdale, R. C., Goering, J. J. (1967). Uptake of new and regenerated forms of nitrogen in primary productivity. Limnol. Oceanogr. 12: 196-206

Erga, S.-R., Heimdal, B. R. (1984). Ecological studies of the phytoplankton of Korsfjorden, western Norway. The dynamics of a spring phytoplankton bloom seen in relation to hydrographical conditions and light regime. J. Plankton Res. 6: 67-90

Fransz, H. G. (1976). The spring development of calanoid copepod populations in the Dutch coastal waters as related to primary production. In: Persoone, G., Jaspers, E. (ed.) Proceedings of the 10th European Marine Biology Symposium, Ostend, Belgium, Vol. 2. Universa Press, Wetteren, p. 247-269

Gaarder, T. (1916). De vestlandske fjorders hydrografi Bergens Mus. Aarb. 1915-1916. Naturv. Raekke, Nr. 2

Gardner, W. D. (1980). Sediment trap dynamics and calibration: a laboratory evaluation. J. mar. Res. 38: 17-39

Gardner, W. D., Hinga, K. R., Marra, J. (1983). Observations on the degradation of biogenic material in the deep ocean with implications on accuracy of sediment trap fluxes. J. mar. Res. 41: 195-214

Gieskes, W. W. C., Kray, K. M. (1977). Primary production and consumption of organic matter in the southern North Sea during the spring bloom of 1975. Neth. J. Sea Res. 11: 146-167

Glenne, B., Simensen, T. (1963). Tidal current choking in the landlocked fjord of Nordåsvannet. Sarsia 11: 43-73

Grasshoff, K. (1976). Methods of sea-water analysis. Verlag Chemie, Weinheim

Hargrave, B. T., Taguchi, S. (1978). Origin of deposited material sedimented in a marire bay. J. Fish. Res. Bd Can. 35: $11604-1613$

Hargrave, B. T., Burns, N. M. (1979). Assessment of sediment trap collection efficiency. Limnol. Oceanogr. 24: $1124-1136$

Hendrikson, P. (1976). Abbauraten von organischem Kohlenstoff im Seston und in Sinkstoffen der Kieler Bucht. Kieler Meeresforsch., Sonderheft 3: 105-119

Holm-Hansen, O., Lorenzen, C. J., Holmes, R. W., Strickland, J. D. H. (1965). Fluorometric determination of chlorophyll. J. Cons. perm. int. Explor. Mer 30: 3-15

Indrebø, G., Pengerud, B., Dundas, I. (1979). Microbial activities in a permanent stratified estuary. I. Primary production and sulfate reduction. Mar. Biol. 51: 295-304

Iseki, K., Whitney, F., Wong, C. S. (1980). Biochemical changes of sedimented matter in sediment traps in shallow coastal waters. Bull. Plankton Soc. Japan 27: 27-36

Iturriaga, R. (1979). Bacterial activity related to sedimentation of particulate matter. Mar. Biol. 55: 157-169

Johannessen, P. J. (1972). Undersøkleser i Nordåsvannet 1969-1970: Hydrografi, planktoniske copepoder og en kort oversikt over meduser og ctenophorer. Unpublished cand. real. thesis, University of Bergen, Norway

Johannessen, P. J. (1983). Overvåkning av fjordene rundt Bergen 1982. 'Byfjord-undersøkelsen' Institutt for marinbiologi: Rapportserie nr. 3: 1-65

Johannessen, P. J. (1985). The natural hydrographic conditions in Nordåsvannet. Sarsia (in press)

Knauer, G. A., Martin, J. H. (1981). Phosphorus-cadmium cycling in northeast Pacific waters. J. mar Res. 39:65-76

Lännergren, C., Skjoldal, H. R. (1976). The spring phytoplankton bloom in Lindåspollene, a land-locked Norwegian fjord. Autotrophic and heterotrophic activities in relation to nutrients. In: Persoone, G., Jaspers, E. (ed.) Proceedings of the $10^{\text {th }}$ European Marine Biology Symposium, Ostend, Belgium, Vol. 2. Universa Press, Wetteren, p. 363-391

Lee, C., Wakeham, S. G., Farrington, J. W. (1983). Variations in organic matter in a time-series sediment trap. Mar. Chem. 13: 181-194

Lie, U., Magnesen, T., Tunberg, B., Aksnes, D. (1983). Preliminary studies on the vertical distribution of size-fractions in the zooplankton community in Lindaspollene, Western Norway. Sarsia 68: 65-80

Lorenzen, C. J. (1967), Vertical distribution of chlorophyll and 
phaeopigments - Baja California. Deep Sea Res. 14: 735-746

Lorenzen, C. J. (1974). Chlorophyll-degradation products in the sediments of the Black Sea. In: Degens, E. T., Ross, D. A. (ed.) The Black Sea $\rightarrow$ geology, chemistry, and biology. The American Association of Petroleum Gelogists, Tulsa, Oklahoma, USA, Memoir 20: 426-428

Lorenzen, C. J., Welshmeyer, N. A. (1983). The in situ sinking rates of herbivore fecal pellets. J. Plankton Res. 5: 929-933

Matthews, J. B. L., Heimdal, B. R. (1980). Pelagic productivity and food chains in fjord systems. In: Freeland, H. J., Farmer, D. M., Levings, C. D. (ed.) Fjord oceanography NATO Conference Series, IV, Marine Science (1980), New York, p. 377-398

Naas, K. E. (1984). Primærproduksjonen in Nordåsvannet, en kloakk belasted poll ved Bergen. Unpubl. cand. scient. thesis, University of Bergen, Norway

Peinert, R., Saure, A., Stegman, P., Stien, C., Haardt, H. Smetacek, V. (1982). Dynamics of primary production and sedimentation in a coastal ecosystem. Neth. J. Sea Res. 16: 276-289

Refield, A. C., Ketchum, B. H., Richards, F. A. (1963). The influence of organisms on the composition of seawater. In: Will, M. N. (ed.) The sea. Wiley-Interscience, New York, p. $26-77$

Richards, F. A., Cline, J. D., Broenkow, W. W., Atkinson, L. P. (1965). Some consequences of the decomposition of organic matter in Lake Nitinat, an anoxic fjord. Limnol. Oceanogr. 10 (Suppl.): 181-201

Shanks, A. L., Trent, J. D. (1979). Marine snow: microscale nutrient patches. Limnol. Oceanogr. 24 : 850-854

Skei, J. (1983a). Geochemical and sedimentological considerations of a permanent anoxic fjord - Framvaren, south Norway. J. sedim. Geol. 36: 131-145

Skei, J. M. (1983b). Permanently anoxic marine basins exchange of substances across boundaries. In: Hallberg, R. (ed.) Environmental biogeochemistry. Ecol. Bull (Stockholm) 35: 419-429
Skjoldal, H. R., Lännergren, C. (1978). The spring phytoplankton bloom in Lindåspollene, a land-locked Norwegian fjord. II. Biomass and activity of net- and nanoplankton. Mar. Biol. 47: 313-323

Smetacek, V. (1980). Annual cycle of sedimentation in relation to plankton ecology in Western Kiel Bight. Ophelia 1 (Suppl.): $65-76$

Smetacek, V., Brockel, K. V., Zeitzschel, B., Zenk, W. (1978). Sedimentation of particulate matter during a phytoplankton spring bloom in relation to the hydrographical regime. Mar. Biol. 47: 211-226

Sokal, R. R., Rohlf, J. F. (1981). Biometry, 2nd ed. W. H. Freeman and Company, San Franzisco

Steele, J. H., Baird, I. E. (1972). Sedimentation of organic matter in a Scottish sea loch. Memorie Ist. ital. Idrobiol. 29 (Suppl.): 73-88

Strøm, K. M. (1936). Land-locked waters. Hydrography and bottom deposits in badly ventilated Norwegian fjords, with remarks. Vidensk.-Akad. Oslo 1 (7): 1-85

Tett, P. (1982). The Loch Eil Project: planktonic pigments in sediments from Loch Ejl and the Firth of Lorne. J. exp. mar. Biol. Ecol. 56: 101-114

Wassmann, P. (1983). Sedimentation of organic and inorganic particulate material in Lindåspollene, a stratified, landlacked fjord in western Norway. Mar. Ecol. Prog. Ser. 13: 237-248

Wassmann, P., Naas, K. E., Johannessen, P. J. (1984). Annual supply and loss of organic carbon in Nordassvannet, a eutrophicated, land-locked fjord in western Norway. Proceedings from the ICES-symposium 'Contaminant fluxes through the coastal zone', Nantes, France, May 1984, no. 32

Wiborg, K. F. (1944). The production of zooplankton in a landlocked fjord. Firskeridirektoratets Skrifter, Serie Havundersøkelser, 7: 1-83 